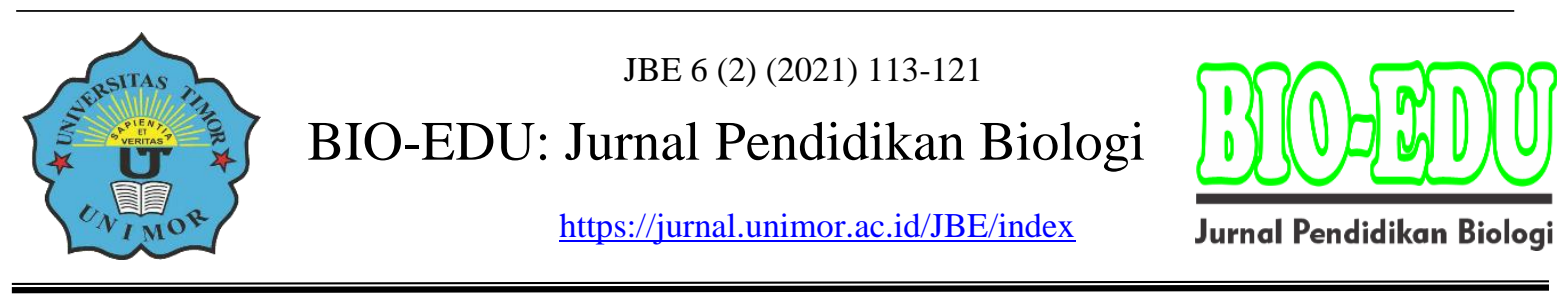

\title{
Optimasi Sterilisasi Endosperma Kepel (Stelecthocarpus burahol [B1] Hook F. \& Th) Secara In Vitro
}

\author{
Etty Handayani ${ }^{1, *}$, Muhammad Burhanuddin Irsyadi ${ }^{1,2}$, Irfan Aris ${ }^{1}$, Riffa Leshia \\ Muhvi Nur Alawiyah ${ }^{1}$, Nandini Ayuningtias ${ }^{3}$, Fany Permatasari ${ }^{1}$, Innaka Ageng \\ Rineksane $^{1}$ \\ ${ }^{1}$ Program Studi Agroteknologi, Fakultas Pertanian, Universitas Muhammadiyah \\ Yogyakarta Jl. Brawijaya, Tamantirto, Kasihan, Bantul, 55676, D. I. Yogyakarta, \\ Indonesia \\ ${ }^{2}$ Departemen PemuliaanTanaman, Fakultas Pertanian, Universitas Gadjah Mada \\ Jl. Flora, Bulaksumur, Depok, Sleman, 55281, D. I. Yogyakarta, Indonesi \\ ${ }^{3}$ Departemen Ilmu Hama Tanaman, Fakultas Pertanian, Universitas Gadjah Mada \\ J1. Flora, Bulaksumur, Depok, Sleman, 55281, D. I. Yogyakarta, Indonesia \\ Email: etty@umy.ac.id
}

\section{DOI: https://doi.org/10.32938/jbe.v6i2.1179}

\begin{abstract}
Abstrak
Kepel (Stelechocarpus burahol [B1] Hook F. \& Th.) merupakan buah asli Indonesia berbiji banyak dengan ukuran yang besar. Bagian buah yang dapat dikonsumsi hanya $49 \%$ dengan bagian lain berupa biji. Perbanyakan kepel secara konvensional masih sulit dilakukan dengan hasil yang rendah. Kultur endosperma secara in vitro adalah metode perbanyakan yang tepat untuk memperoleh tanaman triploid dengan buah tanpa biji. Sterilisasi merupakan tahap awal yang menjadi kunci keberhasilan kultur in vitro. Hingga kini belum dilaporkan metode sterilisasi endosperma kepel secara in vitro yang tepat. Penelitian ini bertujuan untuk memperoleh metode sterilisasi eksplan yang tepat untuk kultur endosperma kepel. Penelitian ini telah dilaksanakan pada bulan September 2018 - Januari 2019 di Laboratorium Kultur In Vitro, Fakultas Pertanian, Universitas Muhammadiyah Yogyakarta. Penelitian ini menggunakan metode eksperimen disusun dalam Rancangan Acak Lengkap (RAL) faktor tunggal dengan perlakuan berbagai konsentrasi bahan sterilan yang terbagi 8 aras: $\mathrm{H}_{2} \mathrm{O}_{2}\left(3 \% 10^{\prime}, 3 \% 15,5 \% 10^{\prime}, 5 \% 15^{\prime}\right) \mathrm{NaOCl}\left(5^{\prime} 5^{\prime}\right.$, 5\%10', 10\%5', 10\%10') dengan 3 kali ulangan dan 3 sempel. Parameter yang diamati yaitu: persentase kontaminasi, browning, hidup, vitrifikasi, jenis kontaminasi, waktu kontaminasi dan waktu browning. Hasil penelitian diperoleh bahwa perlakuan $\mathrm{NaOCl} 10 \%$ selama 10 menit merupakan metode sterilisasi paling tepat dengan presentase ekplan hidup 44,44\%, persentase eksplan vitrifikasi 66,66\%, serta tidak terjadi kontaminasi dan browning.
\end{abstract}

Kata Kunci: Clorox; Endospermaa; Hidrogen peroxida, Kepel; Sterilisasi

\begin{abstract}
Kepel (Stelechocarpus burahol [Bl] Hook F. \& Th.) is an Indonesian original fruit with large seeds and only $49 \%$ of the fruit can be consumed. Conventional propagation of kepel is still difficult with low yields. Endosperma culture in vitro is an appropriate propagation method for obtaining triploid plants with seedless fruit. Furthermore, sterilization is an early stage to successful in vitro culture. Until now, the appropriate method of sterilization of endosperm kepel in vitro has not been reported. This study aims to obtain the appropriate sterilization method for endosperm culture kepel. This research was conducted in September 2018 - January 2019 at the Laboratory of In Vitro Culture, Faculty of Agriculture, Universitas Muhammadiyah Yogyakarta. This study used an experimental method arranged in a single factor
\end{abstract}


Completely Randomized Design (CRD) with the treatment of various concentrations of sterilant divided into 8 levels: $\mathrm{H}_{2} \mathrm{O}_{2}$ (3\%10 ', 3\%15', 5\%10 ', 5\%15') $\mathrm{NaOCl}(5 \% 5$ ', 5\%10', 10\%5 ', 10\%10') with 3 repetitions and 3 samples. The parameters observed were: percentage of contamination, browning, life and vitrification, type of contamination, time of contamination and time of browning. The results showed that concentration of $\mathrm{NaOCl} 10 \%$ for 10 minutes was the most appropriate sterilization method with a live explant percentage of $44.44 \%$, percentage of $66.66 \%$ vitrified explants, and not contamination and browning.

Keywords: Clorox; Endosperm; Hydrogen peroxide; Kepel; Sterilization

\section{PENDAHULUAN}

Kepel (Stelechocarpus burahol [Bl] Hook F. \& Th) atau burahol merupakan salah satu tanaman buah asli Indonesia. Kepel menjadi tanaman identitas Daerah Istimewa Yogyakarta pada tahun 1992 (Batubara dkk., 2010). Buah kepel berbentuk bulat oval, berukuran sebesar genggaman tangan dengan warna kecoklatan. Buah dan daun kepel mengandung antioksidan dan flavonoid cukup tinggi. Buah kepel dapat dimanfaatkan untuk menghilangkan bau mulut, mengharumkan bau mulut dan sebagai deodoran oral. Selain itu, kepel berkhasiat sebagai pencegah kanker, radang ginjal, peluruh air kencing dan penurun kadar kolestrol (Elfasyari, 2020; Fiani dan Yuliah, 2018).

Pada saat ini, tanaman kepel mengalami kelangkaan, sehingga keberadaannya sulit ditemukan. Apabila kondisi ini dibiarkan tanaman kepel akan mengalami kepunahan. Kondisi terebut dapat disebabkan karena pertumbuhan tanaman lambat dan sulit dibudidayakan secara konvensional. Selain itu, kelangkaan disebabkan oleh masyarakat yang enggan untuk menanam karena buah kepel memiliki nilai ekonomis yang rendah (Handayani dkk., 2020; Haryjanto, 2012). Hal ini dikarenakan bagian buah kepel yang dapat dikomsumsi hanya 49\%, sementara bagian lainnya hanya berupa biji. Biji kepel berukuran besar dan melintang dalam buah (Tisnadjaja dkk., 2006). Untuk meningkatkan nilai ekonimis kepel, dapat dilakukan pemuliaan tanaman melalui kultur endosperma untuk memperoleh buah tanpa biji.

Endosperma merupakan massa sel parenkim yang homogen tanpa jaringan pembuluh dan pembelahan yang berada di dalam biji yang berfungsi sebagai cadangan makanan embrio. Kultur endosperma yaitu metode perbanyakan secara in vitro dengan menggunakan eksplan endosperma dari biji untuk mendapatkan tanaman triploid dan buah tanpa biji (Sukamto 2010). Metode ini dilakukan secara in vitro dengan lingkungan terkendali dalam kondisi yang aseptis. Kelebihan perbanyakan secara in vitro yaitu memperoleh bibit dalam jumlah yang banyak dengan waktu relative cepat. Selain itu bibit yang dihasilkan bebas dari serangan hama atau penyakit (Irsyadi, 2021). Faktor keberhasilan dalam kultur endosperma secara in vitro yaitu pada tahap sterilisasi. Sterilisasi merupakan tahap pembersihan eksplan dari kotoran, hama dan mikroba yang masih menempel pada eksplan. Tahapan ini pada umumnya dilakukan dengan pencucian ekplan pada air mengalir serta penambahan bahan sterilan seperti deterjen, bakterisida, fungisida, Sodium hipoklorit $(\mathrm{NaOCl})$ dan Hidrogen peroksida $\left(\mathrm{H}_{2} \mathrm{O}_{2}\right)$. Kondisi eksplan tidak steril dapat mengakibatkan kontaminasi yang dapat menghambat pertumbuhan eksplan. Selain itu, sterilisasi kurang tepat dapat memicu muncul browning pada permukaan eksplan (Suratman dan Mulyani, 2013).

Hingga kini, metode sterilisasi eksplan endosperma kepel optimal belum pernah dilaporkan. Maka perlu dilakukan pengujian terhadap bahan sterilan untuk sterilisasi endosperma kepel. Penelitian ini bertujuan untuk memperoleh metode sterilisasi ekplan 
endoperm kepel yang tepat pada kultur endosperma secara in vitro.

\section{METODE}

\section{Waktu dan Tempat}

Penelitian ini telah terlaksana pada bulan September 2018 hingga Januari 2019 di Laboratorium Kultur In Vitro, Fakultas Pertanian, Universitas Muhammadiyah Yogyakarta. Jl. Brawijaya, Tamantirto, Kasihan, Bantul, D. I. Yogyakarta, Indonesia.

\section{Bahan dan Alat}

Bahan yang digunakan yaitu biji kepel. aquades, larutan deterjen $2 \mathrm{~g} / \mathrm{l}$, larutan bakterisida $2 \mathrm{~g} / \mathrm{l}$ dan fungisida $2 \mathrm{~g} / \mathrm{l}$, alkohol $70 \%, \mathrm{NaOCl}, \mathrm{H}_{2} \mathrm{O}_{2}$, Media Murashige and Skoog + 2,4 D $2 \mathrm{ppm}+$ BAP 0,5 ppm. Alat yang digunakan yaitu: autoclave, laminar air flow, scalpel, pinset, petridisk, erlenmeyer, botol kultur, gelas ukur, timbangan analitik dan lampu UV serta bunsen.

\section{Prosedur Penelitian}

Penelitian ini telah dilakukan menggunakan Rancangan Acak Lengkap (RAL) faktor tunggal dengan perlakuan berbagai konsentrasi bahan sterilan yang terdiri dari 8 aras: $\mathrm{H}_{2} \mathrm{O}_{2}\left(3 \% 10^{\prime}, 3 \% 15^{\prime}, 5 \% 10^{\prime}\right.$ dan 5\% 15'), $\mathrm{NaOCl}\left(5 \% 5^{\prime}, 5 \% 10,10 \% 5^{\prime}\right.$ 'dan $10 \% 10$ '), setiap perlakuan diulang sebanyak 3 kali dan setiap ulangan terdiri dari 3 sempel.

Pra sterilisasi: Buah kepel yang telah masak diperoleh dari sekitar Yogyakarta dicuci menggunakan air mengalir. Setelah itu biji kepel dipisahkan dari daging buah. Biji kemudian dicuci hingga bersih menggunakan air mengalir. Selanjutnya biji dilakukan Pra-sterilisasi dengan direndam dalam larutan deterjen 2 g/l selama 10 menit. Setela itu, biji dibilas menggunakan aquades 3 kali kemudian direndam dalam larutan bakterisida dan fungisida masing-masing $2 \mathrm{~g} / 1$ selama 60 menit sambil digojok. Setelah itu biji dibilas menggunakan aquades 3 kali di dalam laminar air flow. Setelah itu, biji dicelupkan ke dalam alkohol $70 \%$ selama 3 detik. Selanjutnya biji ditirskan diatas tisu steril kemudian biji dibelah menggunakan scalpel untuk mengambil endosperma kepel.

Sterilisasi: endosperma kepel disterilisasi sesuai dengan perlakuan masing-masing menggunakan $\mathrm{H}_{2} \mathrm{O}_{2} 3 \%$ selama 10 menit, 3\% selama 15 menit, 5\% selama 10 menit dan $5 \%$ selama 15 menit, $\mathrm{NaOCl} 5 \%$ selama 5 menit, 5\% selama 10 menit, $10 \%$ selama 5 menit dan $10 \%$ selama 10 menit. Setelah itu endosperma dibilas menggunakan aquades 3 kali kemudian dipotong persegi dalam larutan antiseptik. Selanjutnya endosperma diinokulasi pada media Murashige and Skoog + 2,4 D 2 ppm + BAP 0,5 ppm. Eksplan disimpan di ruang inkubasi selama 60 hari pada suhu $23^{\circ} \mathrm{C}$.

Parameter yang diamati antara lain: persentase kontaminasi, persentase browning, persentase eksplan hidup, persentase vitrifikasi, jenis kontamin, waktu kontaminasi dan waktu browning. Data persentase dianalisis menggunakan sidik ragam (ANOVA) pada software R studio, apabila terdapat beda nyata antar perlakuan dilakukan uji lanjut DMRT dengan taraf $\alpha=5 \%$. Sementara data pada parameter jenis kontaminan, waktu kontaminasi dan waktu browning dianalisis secara deskriptif.

\section{HASIL DAN PEMBAHASAN}

\section{Persentase Kontaminasi}

Hasil analisis sidik ragam (ANOVA) yang signifikan menunjukan bahwa berbagai konsentasi $\mathrm{H}_{2} \mathrm{O}_{2}$ dan $\mathrm{NaOCl}$ berpengaruh nyata terhadap persentase kontaminasi (Tabel 1). Kontaminasi hanya terjadi pada 2 pelakuan yaitu $\mathrm{H}_{2} \mathrm{O}_{2} 3 \%$ selama 10 menit sebesar $100 \%$ yang tidak berbeda nyata dengan $\mathrm{H}_{2} \mathrm{O}_{2} 3 \%$ selama 15 menit sebesar 88,88\%, 
sementa pada perlakuan lainnya tidak terjadi kontaminasi. Perlakuan konsentrasi $\mathrm{NaOCl}$ $5 \%$, $10 \%$ dan $\mathrm{H}_{2} \mathrm{O}_{2} 5 \%$ dapat menekan kontaminasi pada eksplan. Keberadaan endosperma di dalam biji kondisinya steril sehingga tidak terdapat mikroba endogen. Kontaminasi dapat disebabkan karena kondisi eksplan atau media yang kurang steril. Nasution (2013) menjelaskan bahwa kontaminan dapat berasal dari sumber eksplan, peralatan yang digunakan, lingkungan dan tangan yang kurang steril saat di dalam laminar air flow.

$\mathrm{NaOCl}$ merupakan disinfektan yang bersifat hipertonis yang dapat mengakibatkan mikroorganisme mengalami hidrolisis secara osmosis (Permatasari 2013). Singh dkk., (2011) menambahkan bahwa $\mathrm{NaOCl}$ merupakan desinfektan derajat tinggi yang aktif mengendalikan mikroba. Hasil penelitian Rineksane dkk., (2012) bahwa sterilisasi biji Manggis Gracinea mangostana L. menggunakan $\mathrm{NaOCl} 5 \%$ mampu menekan tingkat kontaminasi sebanyak 9,75\%. Srivastava dkk., (2010) melaporkan bahwa $\mathrm{H}_{2} \mathrm{O}_{2}$ mampu menggumpalkan protein mikroba sehingga akan kehilangan fungsinya. Hasil penelitian Farooq dkk., (2002) bahwa penggunaan $\mathrm{H}_{2} \mathrm{O}_{2} 12 \%$ selama 15 menit mampu mencegah kontaminsi pada sterilisasi permukaan pada biji srikaya Annona Squamosa sebanyak 50\%. Selain itu, Martiansyah dkk., (2013) melaporkan bahwa penggunaan konsentrasi $\mathrm{H}_{2} \mathrm{O}_{2}$ yang umum digunakan untuk sterilisasi permukaan eksplan berkisar 3-20\%. Akan tetapi, pada konsentrasi 3\% belum mampu mengendalikan kontaminasi diduga waktu yang dibutuhkan terlalu cepat dibanding perlakuan lainnya karena jumlah konsentrasi sedikit memerlukan waktu lebih lama untuk mengendalikan mikroba dalam jaringan tanaman.

Table 1. Pengaruh Konsentrasi $\mathrm{NaOCl}$ dan $\mathrm{H}_{2} \mathrm{O}_{2}$ Terhadap Sterilisasi Endosperma Kepel

\begin{tabular}{lccc}
\hline Perlakuan & $\begin{array}{c}\text { Persentase } \\
\text { Kontaminasi (\%) }\end{array}$ & $\begin{array}{c}\text { Jenis } \\
\text { Kontaminan }\end{array}$ & $\begin{array}{c}\text { Waktu Kontaminasi } \\
\text { (HST) }\end{array}$ \\
\hline $\mathrm{H}_{2} \mathrm{O}_{2}$ 3\% 10 menit & $100 \mathrm{a}$ & Bakteri & 11 \\
$\mathrm{H}_{2} \mathrm{O}_{2}$ 3\% 15 menit & $88,89 \mathrm{a}$ & Bakteri & 8,6 \\
$\mathrm{H}_{2} \mathrm{O}_{2} 5 \%$ 10 menit & $0 \mathrm{~b}$ & - & - \\
$\mathrm{H}_{2} \mathrm{O}_{2} 5 \%$ 15 menit & $0 \mathrm{~b}$ & - & - \\
$\mathrm{NaOCl} 5 \%$ 5 menit & $0 \mathrm{~b}$ & - & - \\
$\mathrm{NaOCl} \mathrm{5 \%} \mathrm{10} \mathrm{menit}$ & $0 \mathrm{~b}$ & - & - \\
$\mathrm{NaOCl} \mathrm{10 \%} \mathrm{5} \mathrm{menit}$ & $0 \mathrm{~b}$ & - & - \\
$\mathrm{NaOCl} \mathrm{10 \%} \mathrm{10} \mathrm{menit}$ & $0 \mathrm{~b}$ & - & - \\
\hline $\mathbf{C V} \%$ & $\mathbf{2 8 , 8 1}$ & - & - \\
\hline
\end{tabular}

Keterangan: Angka-angka yang diikuti dengan huruf yang sama tidak berbeda nyata antar perlakuan pada uji lanjut DMRT dengan taraf $\alpha=5 \%$, HST $=$ hari setelah tanam.

\section{Jenis dan Waktu Kontaminasi}

Berdasarkan pada tabel 1, dapat diketahui bahwa jenis kontaminan yang muncul pada perlakuan $\mathrm{H}_{2} \mathrm{O}_{2} 3 \% 10$ menit dan 15 menit berupa bakteri pada hari ke 11 dan 8,6 setelah tanam. $\mathrm{NaOCl}$ sebagai bahan sterilan mampu menghilangkan dan membersihkan sumber kontaminan berupa bakteri atau jamur pada eksplan. Kontaminasi bakteri ditandai dengan munculnya lendir putih kekuningan yang menyelimuti permukaan eksplan hingga media. Semakin lama waktu yang digunakan maka seluruh permukaan eksplan dan media akan tertutupi oleh bakteri. Nasution, (2013) melaporkan bahwa 
bakteri mengandung glycocalyx yang mampu untuk menetralisir senyawa antibakteri untuk melindungi diri. Oleh karena itu, pada konsentrasi sterilant rendah, diduga bakteri dapat menetralisir untuk bertahan hidup.

Rismayani dan Hamzah (2010) melaporkan bahwa kontaminasi pada eksplan dapat menghambat pertumbuhan hingga dapat mengakibatkan kematian eksplan. Hal ini dikarenakan terjadi persaingan penyerapan nutrisi media antara eksplan dengan bakteri atau jamur. Lama waktu kontaminasi lebih dari seminggu setelah tanam diduga disebabkan oleh mikroba endogen yang tertinggal dalam eksplan, sehingga membutuhkan waktu lebih lama untuk muncul. Shofiyani dan Damajanti (2017) melaporkan bahwa kontaminasi internal yang disebabkan mikroba endogen terjadi lebih dari 10 hari setelah tanam, sedangkan kontaminasi eksternal (eksogen) dapat terjadi beberapa hari setelah tanaman.

\section{Persentase Hidup}

Berdasarkan hasil analisis sidik ragam (ANOVA) tidak signifikan maka perlakuan berbagai konsentrasi $\mathrm{NaOCl}$ dan $\mathrm{H}_{2} \mathrm{O}_{2}$ tidak berpengaruh nyata terhadap persentase eksplan hidup (Tabel 2). Perolehan persentase eksplan hidup cenderung lebih baik pada perlakuan $\mathrm{NaOCl} 10 \%$ selama 10 menit sebesar 44,44\% dibanding dengan perlakuan lainnya. Pada perlakuan $\mathrm{H}_{2} \mathrm{O}_{2} 3 \%$ persentase eksplan hidup $0 \%$ karena mengalami kontaminasi dan browning. Tingkat persentase hidup rendah dikarenakan banyaknya eksplan yang mengalami vitrifikasi. Ekplan hidup ditandai dengan perkembangan eksplan yang tidak mengalami kontaminasi dan browning. Kultur endosperma tanpa penyertaan embrio sulit untuk pembentukan kalus. Hasil penelitian Sukamto (2010) menyatakan bahwa kultur endosperma alpukad Persea americana Mill. tanpa penyertaan embrio tidak terjadi pertumbuhan kalus, tetapi eksplan endosperma yang disertai embrio memperoleh persentase terbentuk kalus mencapai $44,85 \%$ pada 15 minggu setelah tanam.

Umur endosperma muda pada fase meristemik merespon baik bila dikulturkan. Umur endosperma tua juga dapat digunakan untuk kultur endosperma (Tao dkk., 1996). Menurut Nair dkk., (1986) bahwa penggunaan endosperma srikaya Annona squamosa Linn tua dapat digunakan untuk kultur endosperma. Eksplan yang tidak dilakukan sterilisasi lebih lanjut dapat menurunkan hasil kultur endosperma. Hasil penelitian Prabakti dkk., (2017) sterilisasi endosperma kluwek Pangium edule Reinw hanya menggunakan aquades steril ditambah antiseptik selama 3 menit diperoleh persentase berkalus hanya mencapai $18,8 \%$. Kundu dkk., (2017) melaporkan bahwa penggunaan bahan sterilant $\mathrm{NaOCl}$ dengan konsentrasi 5 - 10\% selama 5 - 10 menit dapat digunakan untuk sterilisasi permukaan biji.

\section{Persentase Vitrifikasi}

Berdasarkan hasil analisis sidik ragam (ANOVA) yang signifikan menunjukkan bahwa perlakuan berbagai konsentrasi $\mathrm{NaOCl}$ dan $\mathrm{H}_{2} \mathrm{O}_{2}$ berpengaruh nyata terhadap persentase eksplan vitrifikasi (Tabel 2). Perolehan persentase vitrifikasi tertinggi pada perlakuan $\mathrm{NaOCl} 10 \%$ selama 10 menit sebesar $66,66 \%$ yang berbeda nyata dengan perlakuan lainnya. Vitrifikasi ditandai dengan kondisi eksplan staknasi yang tidak mengalami pertumbuhan dan berwarna putih bening. Kondisi ini apabila berlakngsung lama akan mengalami kematian. Menurut Karyanti dan Ida (2013) vitrifikasi disebabkan oleh kerusakan sel secara fisiologis pada eksplan karena kandungan air dalam medium yang tinggi dan defisiensi klorofil. Kandungan air terlalu tinggi menyebabkan terjadinya 
difusi air ke dalam sel eksplan. Selain itu, vitrifikasi dipengaruhi oleh kandungan sitokinin pada medium dan uap air yang berlebihan hasil respirasi di dalam botol kultur.

\section{Persentase Browning}

Berdasarkan hasil analisis sidik ragam (ANOVA) yang signifikan menunjukkan bahwa perlakuan berbagai konsentrasi $\mathrm{NaOCl}$ dan $\mathrm{H}_{2} \mathrm{O}_{2}$ berpengaruh nyata terhadap persentase eksplan browning. Konsentrasi $\mathrm{NaOCl} 10 \% 10$ menit dan $\mathrm{H}_{2} \mathrm{O}_{2} 3 \%$ selama 10 menit merupakan perlakuan paling baik dengan ditandai tidak mengalami browning, tetapi tidak bebeda nyata dengan perlakuan sterilisasi $\mathrm{H}_{2} \mathrm{O}_{2} 3 \%$ selama 15 menit dengan perolehan sebesar $11,11 \%$. Perolehan persentase browning cenderung tertinggi pada perlakuan $\mathrm{NaOCl} 5 \%$ selama 5 menit sebesar 88,89\%. Browning ditandai perubahan warna eksplan menjadi kecoklatan di permukaan eksplan. Hal ini dapat menghambat pertumbuhan hingga mengakibatkan kematian eksplan. Browning dapat disebabkan adanya luka pada eksplan yang mengakibatkan keluarnya senyawa fenolik. Senyawa yang keluar mengaktifkan enzim polifenol oksidase (PPO) yang teroksidasi oleh oksigen menyebabkan pencoklatan atau browning pada eksplan.

Hatmi dan Widyayanti (2014) melaporkan bahwa biji kepel mengandung senyawa saponin, flavoid, polifenol dan alkaloid. Senyawa Polifenol tersebut yang menyebabkan browning. Penggunaan bahan eksplan yang telah masak dapat memicu terjadinya browning karena kandungan polifenol semakin meningkat. Eksplan yang telah tua akan mengeluarkan hasil oksidasi yang lebih banyak dibandingkan dengan eksplan muda. Hasil penelitian Setiani dkk. (2018) bahwa sterilisasi eksplan daun sukun Artocarpus altilis menggunakan $\mathrm{NaOCl}$ 5,25\% selama 10 menit mengakibatkan browning mencapai 90\%. Hal ini sesuai dengan pernyataan Yang (2009) bahwa clorox dan etanol dengan konsentrasi yang cukup tinggi dapat merusak jaringan eksplan sehingga dapat menyebabkan kerusakan jaringan dan terjadinya browning.

Table 2. Pengaruh $\mathrm{NaOCl}$ dan $\mathrm{H}_{2} \mathrm{O}_{2}$ Terhadap Persentase Hidup, Vitrifikasi, Browning dan Waktu Browning

\begin{tabular}{|c|c|c|c|c|}
\hline \multirow[b]{2}{*}{ Perlakuan } & \multicolumn{3}{|c|}{ Persentase Eksplan } & \multirow[b]{2}{*}{$\begin{array}{l}\text { Waktu Muncul } \\
\text { Browning (HST) }\end{array}$} \\
\hline & Hidup (\%) & $\begin{array}{c}\text { Vitrifikasi } \\
(\%)\end{array}$ & $\begin{array}{l}\text { Browning } \\
(\%)\end{array}$ & \\
\hline $\mathrm{H}_{2} \mathrm{O}_{2} 3 \% 10$ menit & $0 \mathrm{a}$ & $0 \mathrm{~b}$ & $0 \mathrm{c}$ & - \\
\hline $\mathrm{H}_{2} \mathrm{O}_{2} 3 \% 15$ menit & $0 \mathrm{a}$ & $0 \mathrm{~b}$ & $11,11 \mathrm{bc}$ & 5 \\
\hline $\mathrm{H}_{2} \mathrm{O}_{2} 5 \% \quad 10$ menit & $33,33 \mathrm{a}$ & $22,22 \mathrm{~b}$ & $44,45 \mathrm{ab}$ & 5,3 \\
\hline $\mathrm{H}_{2} \mathrm{O}_{2} 5 \% 15$ menit & $22,22 \mathrm{a}$ & $11,11 \mathrm{~b}$ & $66,67 \mathrm{a}$ & 3 \\
\hline $\mathrm{NaOCl} 5 \% 5$ menit & $11,11 \mathrm{a}$ & $0 \mathrm{~b}$ & $88,89 \mathrm{a}$ & 15 \\
\hline $\mathrm{NaOCl} 5 \% 10$ menit & $33,33 \mathrm{a}$ & $11,11 \mathrm{~b}$ & $55,56 \mathrm{ab}$ & 16,33 \\
\hline $\mathrm{NaOCl} 10 \% 5$ menit & $33,33 \mathrm{a}$ & $22,22 \mathrm{~b}$ & $44,45 \mathrm{ab}$ & 24 \\
\hline $\mathrm{NaOCl} 10 \% 10$ menit & $44,44 \mathrm{a}$ & 66,66 a & $0 \mathrm{c}$ & - \\
\hline $\mathrm{CV} \%$ & 65,7 & 76,45 & 45,17 & - \\
\hline
\end{tabular}

Keterangan: Angka-angka yang diikuti dengan huruf yang sama tidak berbeda nyata antar perlakuan pada uji lanjut DMRT dengan taraf $\alpha=5 \%$, HST $=$ hari setelah tanam.

\section{Waktu Muncul Browning}

Waktu muncul browning merupakan parameter untuk mengetahui kecepatan eksplan mengalami browning. hasil penelitian menunjukkan bahwa perlakuan $\mathrm{NaOCl}$ 
10\% selama 5 menit dengan waktu paling lama 24 HST untuk muncul browning, sedangkan waktu muncul browning cenderung cepat pada perlakuan $\mathrm{H}_{2} \mathrm{O}_{2} 3 \%$ selama 15 menit dan 5\% selama 10 dan 15 menit pada hari ke 3-5,3 setelah tanam (Tabel 2). Pada sterilisasi yang optimal dapat menghilangkan senyawa fenol yang berada di permukaan eksplan. Kecepatan browning diduga dapat dipengaruhi oleh tingkat kematangan biji kepel. Hal ini sesuai dengan pernyataan Hatmi dan Widyayanti (2014) bahwa semakin tua umur eksplan akan meningkatkan kandungan senyawa polifenol, sehingga waktu browning lebih cepat dibanding eksplan yang masih muda. Rismayani dan Hamzah (2010) menambahkan bahwa proses pembilasan pada tahap sterilisasi membantu mengeluarkan fenol pada eksplan sehingga dapat menghambat proses browning.

\section{KESIMPULAN DAN SARAN}

\section{Kesimpulan}

Berdasarkan hasil penelitian dapat disimpulkan bahwa terdapat beda nyata antar perlakuan pada persentase eksplan kontaminasi, browning dan vitrifikasi. Sterilisasi endosperma kepel paling optimal menggunakan konsentrasi $\mathrm{NaOCl} 10 \%$ selama 10 menit dengan perolehan persentase eksplan hidup $44,44 \%$ dan persentase vitrifikasi $66,66 \%$ serta tidak mengalami kontaminasi dan browning.

\section{Saran}

Perlu dilakukan penelitian lebih lanjut munggunakan bahan sterilan lain dan jenis ekplan yang berbeda pada kultur in vitro kepel.

\section{DAFTAR RUJUKAN}

Batubara, Irmanida, Latifah K. Darusman, Edy Djauhari, and Tohru Mitsunaga. 2010. "Potency of Kepel (Stelechocarpus Burahol) as Cyclooxigenase-2 Inhibitor." Indonesian Journal of Plant Medicine 3(2):110-14.

Elfasyari, Trie Yuni. 2020. "Penetapan Kadar Flavonoid Total Pada Beberapa Bagian Tanaman Kepel (Stelecocharpus Burahol Hook F. \& Th)." Jurnal Farmasi Udayana; Vol. 8, No. 2, Tahun 2019. DOI - 10.24843/JFU.2019.V08.I02.P08 .

Farooq, S. A., T. T. Farooq, and T. V Rao. 2002. "Micropropagation of Annona Squamosa L. Using Nodal Explants." Pakistan Journal of Biological Sciences 5(1):43-46. DOI: 10.3923/pjbs.2002.43.46.

Fiani, A., and Yuliah. 2018. "Pertumbuhan Kepel (Stelechocarpus Burahol (Blume) Hook \& Thomson) Dari Dua Populasi Di Mangunan, Bantul." Pp. 301-6 in Prosiding SEMINAR NASIONAL PENDIDIKAN BIOLOGI DAN SAINTEK III. 5 Mei. Sukoharjo.

Handayani, E., Nandariyah, V. R. Cahyani, and Parjanto. 2020. "Morphological Characters of Kepel (Stelechocarpus Burahol) from Kulon Progo, Yogyakarta, Indonesia." in IOP Conference Series: Earth and Environmental Science. Vol. 458.

Haryjanto, L. 2012. "Konservasi Kepel (Stelechocarpus Burahol (Blume) Hook. f \& Thomson): Jenis Yang Telah Langka." Mitra Hutan Tanaman 7(1):11-17. 
Hatmi, Retno Utami, and Setyorini Sudarmaji Widyayanti. 2014. "Potensi Kepel (Stelechocarpus Burahol [Blume] Hook.F \& Th.) Sebagai Sumber Pangan Fungsional." Pp. 248-57 in Prosiding Seminar Nasional Sumber Daya Genetik Pertanian,.

Irsyadi, Muhammad Burhanuddin. 2021. "Factors That Effect of the Optimal Plantlet Growth from Tissue Culture on the Acclimatization Stage." Pp. 100-104 in Proceeding International Conference on Science and Engineering, 23 October. Yogyakarta, Oktober 23.

Karyanti, J., and R. Ida. 2013. "Pemanfaatan Bahan Teknis KNO3, CACL2, MGSO4, KH2PO4 Sebagai Hara Makro Dan Benzil Adenin Dalam Perbanyakan Jati (Tectona Grandis L) Secara In Vitro." Jurnal Sains Dan Teknologi Indonesia 14(3):203-8.

Kundu, Monoj, Jayesh Pathak, and Sangita Sahni. 2017. "Embryo Culture and Endosperm Culture." Pp. 125-40 in Plant Biotechnologi.

Martiansyah, I., D. D. Eris, H. Nurhaimi, and D. Taniwiryono. 2013. "Optimasi Prosedur Sterilisasi Permukaan Eksplan Stek Mikro Karet (Hevea Brasiliensis Muell. Arg)." Menara Perkebunan 81:9-14.

Nair, S., Shirgukar, and Mascarenhas. 1986. "Studies on Endosperm Culture of Annona Squamosal Linn.” Plant Cell Report 5:132-35. DOI: 10.1007/BF00269252

Nasution, S. 2013. "Pengaruh Teknik Strerilisasi Terhadap Keberhasilan Inisasi Eksplan Paulownia (Paulownia Elongata SY. Hu) Secara In Vitro.” [Thesis] Institut Pertanian Bogor. Bogor.

Permatasari, I. Z. 2013. "Uji Efektivitas Natrium Hipoklorit Dalam Menghambat Pertumbuhan Pseudomonas Aeruginosa Secara In Vitro." [Skripsi] Universitas Muhammadiyah Semarang. Semarang

Prabakti, Hendy D., Didik Pudji Restanto, and Sholeh Avivi. 2017. "Pengaruh Macam Eksplan Dan Konsentrasi 2,4 D Terhadap Induksi Kalus Kluwek (Pangiun Edule Reinw.) Secara In Vitro." Gontor AGROTECH Science Journal 3(2):39-58. DOI: 10.21111/agrotech.v3i2.930

Rineksane, I. A., A. K. Mihdzar, K. Saleh, and Q. Z. Faridah. 2012. "In Vitro Development of Embryogenic Calli And Embryogenic Stages In Suspension Cultures of Mangosteen (Garcinia Mangostana L." Journal of Medicinal Plants Research 6(13):2548 - 2559.

Rismayani, and F. Hamzah. 2010. "Pengaruh Pemberian Chlorox (NaOCl) Pada Sterilisasi Permukaan Untuk Perkembangan Bibit Aglaonema (Donna Carmen) Secara In Vitro." in Prosiding Seminar Ilmiah dan Pertemuan Tahunan PGJ dan PEJ XX. Maros, Sulawesi Selatan.

Setiani, Nur Asni, Fitri Nurwinda, and Dewi Astriany. 2018. "Pengaruh Desinfektan Dan Lama Perendaman Pada Sterilisasi Eksplan Daun Sukun (Artocarpus Altilis (Parkinson Ex. F.A Zorn) Fosberg)." Biotropika: Journal of Tropical Biology; Vol 6, No 3 (2018). DOI - 10.21776/Ub.Biotropika.2018.006.03.01. 
Shofiyani, Anis, and Neni Damajanti. 2017. "Pengembangan Metode Sterilisasi Pada Berbagai Eksplan Guna Meningkatkan Keberhasilan Kultur Kalus Kencur (Kaemferia Galangal L)." Agritech: Jurnal Fakultas Pertanian Universitas Muhammadiyah Purwokerto 17(1):55-64. doi: 10.30595/agritech.v17i1.1345.

Singh, V., A. Tyagi, P. K. Clrauhan, P. Kumari, and S. Kaushal. 2011. "Idenrification And Prevention Of Bacterial Contimination On Explant Used In Plant Tissue Culture Labs." International Journal of Pharmacy and Pharmaceutical Sciences 3(4):160-63.

Srivastava, N., B. Kamal, V. Sharma, Y. K. Negi, A. K. Dobriyal, S. Gupta, and V. S. Jadon. 2010. "Standardization of Sterilization Protocol for Micro-Propagation of Aconitum Heterophyllum an Endangered Medicinal Herb." Acad Arena 6(2):6266.

Sukamto, A. 2010. "Kultur In Vitro Endosperma, Protokol Yang Efisien Untuk Mendapatkan Tanaman Triploid Secara Langsung." Jurnal Agro Biogen 6(2):10712. DOI: 10.21082/jbio.v6n2.2010.p107-112.

Suratman, A. P., and S. Mulyani. 2013. "Keefektifan Penggunaan Bahan Sterilisasi Dalam Pengendalian Kontaminasi Eksplan Pada Perbanyakan Tanaman Sirsak (Annona Muricata L.) Secara In Vitro." Publikasi Hasil Penelitian Hibah Bersaing Dikti 1-8.

Tao, R., K. Ozawa, M. Tamura, and A. Sugiura. 1996. "Dodecaploid Plant Regeneration from Endosperm Culture of Persimmon (Diospyros Kaki L.)." Pp. 119-28 in I International Persimmon Symposium.

Tisnadjaja, D., D. E. Saliman, Silvia, and P. Simanjuntak. 2006. "Pengkajian Burahol (Stelechocarpus Burahol (Blume) Hook \& Thomson) Sebagai Buah Yang Memiliki Kandungan Senyawa Antioksidan.” Biodiversitas 7(2):199-202. DOI: 10.13057/biodiv/d070223.

Yang, Z. 2009. "Vegetatif Propagation and Genetic Fingerprinting OF Eucalyptus Grandis and Eucalyptus Amplifolia." University of Florida. 